\title{
Quando o rádio já não é mais um simples eletrodoméstico: sobre as rupturas geracionais no ambiente familiar ${ }^{1}$
}

\author{
Anderson LOPES DA SILVA ${ }^{2}$
}

KASEKER, Mônica Panis. Modos de ouvir: A escuta do rádio ao longo de três gerações. Curitiba: Editora Champagnat, 2012.

Já faz um tempo que o veículo rádio não é mais considerado somente um aparelho eletrônico doméstico tal qual uma geladeira ou um microondas. À primeira vista esta comparação de utilidades e funções parece ser tosca, mas representa bem aquilo que o rádio brasileiro tem passado, de maneira vitoriosa, diga-se de passagem, há muitos anos. Mas: Quando é que o rádio brasileiro foi considerado - ainda que por pouco tempo - "só" mais um eletrodoméstico? Em quais momentos ele (quase) existiu apenas como "adereço" ou outro objeto qualquer da casa?

Quem provoca esse questionamento no leitor é a autora de "Modos de Ouvir: a escuta do rádio ao longo de três gerações”, de Mônica Panis Kaseker, mestre e doutora em Sociologia pela UFPR e professora dos cursos de Comunicação Social da PUCPR, que faz nessa obra um importante estudo sobre as formas de apreensão e escuta deste veículo por meio da ruptura geracional no ambiente familiar em avós, filhos e netos ouvintes do rádio na cidade de Curitiba-PR.

Pesquisando o esquecido "patinho feio" das comunicações, como ela mesma define o rádio, Mônica Kaseker fornece algumas pistas para as perguntas feitas acima. Segundo ela, um dos motivos de se pensar este aparelho como um mero eletrodoméstico em franca desvantagem com outros meios de comunicação, pode ser visto nos altos e baixos pelos quais ele passou desde sua fase áurea, na década de 1940, aos seus momentos de maior declínio com a "invasão" da televisão nos anos de 1950 e 60 e,

\footnotetext{
${ }^{1}$ Trabalho apresentado à quarta edição da Revista Ação Midiática - Estudo em Comunicação, Sociedade e Cultura, publicação esta ligada ao Programa de Pós-Graduação em Comunicação da Universidade Federal do Paraná.

2 Jornalista (FACNOPAR), especialista em Comunicação, Cultura e Arte (PUCPR) e mestrando em Comunicação pela Universidade Federal do Paraná. Bolsista Capes. E-mail: anderlopps@gmail.com.
} 
algumas décadas depois, quando do surgimento da gigantesca (que não se contenta em ser apenas "grande") rede mundial de computadores: a internet.

Nestes períodos o aparecimento de outros meios parecia sentenciar o fim do rádio como uma opção à informação, à cultura e ao entretenimento frente a aparelhos tão modernos e cheios de inovação. O rádio, para os mais pessimistas e apocalípticos, estava condenado a ser um objeto esquecido num quarto ou tido como uma das mais precoces peças de museu.

Entretanto, como é comum em momentos de crises num sistema capitalista e culturalmente industrial, o rádio brasileiro mais uma vez conseguiu, anos após anos, "reinventar-se" e manter-se no ar. Seja pela ideia de segmentação de público ou pela adaptação da atitude de escuta transmidiática por meio da internet e MP3, por exemplo, lá estava ele: presente nos carros, nos computadores, nas casas. Ou seja: novamente o rádio provava que estava muito além de um mero "eletrodoméstico" descartável.

Assim, dividindo a obra - inicialmente uma tese doutoral - em cinco grandes eixos, Kaseker apresenta de modo didático seu aporte teórico, reflexivo e as etapas de seu estudo de recepção. Mostrando logo nos primeiros capítulos a relevância do espaço social da escuta e as relações entre o rádio e a ideia de sociabilidade, a autora vai construindo uma trama de interligações entre o conceito bourdieusiano de habitus e a forma como a escuta no espaço familiar tem íntimos vínculos com o processo de formação de identidade, gosto musical, estilo de vida e formas de apreensão de sentido.

Em outras palavras, apropriando-se da fala do sociólogo francês, Mônica Kaseker (2012, p. 42) aponta que o habitus é um conhecimento adquirido, um capital que possui dentro de si agentes que se apropriam de crenças, jogos de linguagem, aspectos materiais e históricos para criar uma relação dialética entre sujeito e sociedade. E é exatamente pelo fato de cada habitus possuir sua própria essência e autonomia, mais precisamente no espaço familiar, que há a possibilidade de cruzamento de gostos, experiências estéticas e inter-relações entre estes campos, mesmo em diferentes gerações.

Gerações que possuem "formas de pensar e agir" distintas, mas que, pela convivência e a partilha das experiências, conversam entre si. É o que Margaret Mead chama de "cultura pós-figurativa, pré-figurativa e co-figurativa", ou seja, o espaço da diferença onde as pessoas de diversas idades aprendem pela troca de informações e discussões de novas ideias por meio das relações sociais. São as culturas viventes de 
diferentes graus de complexidade, como explica Mead (1997, p. 32), que, reafirmadas no comentário de Martín-Barbero (2002, p. 326), representam estes três tipos de "momento cultural" que compreendem a envergadura antropológica das mudanças e dos dispositivos de diálogo entre gerações e povos.

Dando sequência a isso e traçando um contexto histórico-social do meio de comunicação radiofônico no Brasil e no Paraná, até chegar ao seu locus de estudo, a capital do estado, Mônica Kaseker distingue nessa trajetória cronológica a situação atual das emissoras de rádio AM e FM na cidade. A pesquisadora faz uma detalhada reconstituição iniciando pelos fatos históricos, pelo direcionamento das mensagens e públicos-alvo, por aspectos jurídicos (como as concessões) e chega até à abordagem de alguns conteúdos específicos que são veiculados nas rádios curitibanas.

Com tabelas explicativas sobre os números da audiência, a classe social, o gênero, a idade e a segmentação por gosto (gospel, rock, notícias, etc.), a obra apresenta dados referentes à totalidade das rádios de amplitude e frequência modulada na cidade. O diferencial que faz com que a autora seja merecedora de crédito está justamente na organização de dados que se encontram à disposição de qualquer pesquisador, mas que, muitas vezes, estão dispersos e sem conexões entre si.

Ao fim destes dois eixos, a autora depara-se com um aspecto crucial da discussão do rádio e da interação dos ouvintes com as novas formas de recepção na contemporaneidade. O pensamento de Kaseker conflui para aquilo que Nera Del Bianco, também comentando sobre a convergência midiática, entende como um processo de bricolagem, novos nexos e hibridações produzidas nessa constante "sobrevivência" radiofônica que vai além de uma mera "mudança tecnológica".

Del Bianco (2012, p.17) afirma que tal convergência: "é um processo cultural a considerar que o fluxo de conteúdo que perpassa múltiplos suportes e mercados midiáticos e os consumidores migram de um comportamento de espectadores passivos para uma cultura mais participativa [...]". E completa afirmando que esse processo: "representa uma nova maneira de interagir com meios tradicionais, estabelecendo um outro patamar de cultura de relacionamento com o público".

É sobre este aspecto, o da recepção, que o terceiro eixo da obra de Mônica Kaseker procura tratar ligando a compreensão do termo às ideias de consumo e apropriação no viés dos Estudos Culturais e, mais aprofundadamente, no sentido que o pensamento da Escola Latinoamericana de Comunicação confere a estes conceitos. Ao 
reafirmar a posição de que soa ridículo pensar a comunicação nos moldes de uma produção (ativa) e uma recepção (passiva), isto é, fragmentada, tendo dois extremos distintos e com funções diametralmente opostas, a autora apresenta aquilo que pesquisadores como Jesús Martín-Barbero, Néstor García Canclini e Guillermo Orozco Gómez, entendem por recepção.

Dito de outro modo: o conceito de recepção visto a partir de pessoas possuidoras de história, contextos e entornos culturais que, ao exercerem uma recepção ativa assumidamente baseada no dialogismo bakhtiniano - trocam de posição constantemente nos papéis de emissor e receptor, promovendo, assim, uma mediação cultural e simbólica no cotidiano (MARTÍN-BARBERO, 2009, p. 309).

Uma recepção que ressignifica, ressemantiza e reapropria-se dos conteúdos midiáticos, num processo de leitura crítica e, mais do que isso: na produção e refuncionalização da mídia tradicional em favor de demandas próprias da família, do grupo, do bairro ou da escola. "Na América Latina, os estudos de recepção têm adquirido uma perspectiva metodológica qualitativa e muito focada na cultura popular. Os principais eixos temáticos nas investigações relacionam a recepção midiática à educação, à política e à cultura”, assinala Kaseker (2012, p. 138).

Dessa maneira, é usando os pressupostos teóricos destes pensadores latinoamericanos que a pesquisadora descreve as multimediações (ideia advinda de MartínBarbero, mas "desdobrada", por assim dizer, por Orozco Gómez) num conjunto que abarca a mediação da escuta em cinco critérios. A saber: a mediação tecnológica, a mediação cognoscitiva, a mediação situacional, a mediação institucional e a mediação referencial. Novamente, sem perder o foco primeiro de sua pesquisa, a autora relaciona tais mediações à escuta do rádio no âmbito familiar com sua diversidade dos modos de ouvir e "os tempos" da vida.

A partir daí a prática da pesquisa é apresentada ao leitor, já no fim do terceiro eixo e início do quarto, através das duas etapas iniciais do estudo de recepção. Assim, a primeira delas diz respeito a uma sondagem acerca da "recepção em rádio" com 110 estudantes de três turmas de Jornalismo, alunos da autora na PUCPR, no segundo semestre de 2007.

Já na segunda fase, dez famílias destes alunos foram selecionadas para entrevistas e visitas da autora a suas casas. Estas famílias curitibanas viviam à época da pesquisa, de acordo com Kaseker, em vários bairros da cidade (como Batel, Mercês, 


\section{REVISTA AÇÃOMIDIÁTICA - Estudos em Comunicação, Sociedade e Cultura}

Universidade Federal do Paraná

Programa de Pós Graduação em Comunicação

Vol 2. No 2. Ano 2012

Água Verde, Pinheirinho, Boqueirão, entre outros) e faziam parte de um universo social das classes B e C, com casa própria, carros e filhos frequentando a universidade privada.

O quarto eixo da obra resgata o conceito de habitus e o aplica às entrevistas com os jovens alunos de Mônica Kaseker e suas famílias, tratando de temas como a presença do rádio e a noção de desterritorialização, os aspectos distintivos da escuta no processo migratório do rural ao urbano em algumas destas gerações, as relações de poder e gênero na seleção de emissoras, a escuta como valor de uso para o trabalho/mercado profissional, além de apresentar a questão da escuta involuntária e a "herança" de alguns hábitos de avós e pais refletidos nos jovens.

A partilha das experiências estéticas neste ambiente diverso, tanto por fluxos geracionais quanto pela disponibilidade de tecnologias, provoca, no sentido mais estrito que o termo "experienciação" (experiencing) adquire em Louis Quéré (2010, p. 33-34), tensões e conflitos que, por intermédio das ações destes sujeitos e as consequências apresentadas nestas "operações e transações" de sentido, transformam a atitude de escuta numa exemplar forma de interação familiar. Uma interação que dá mostras de um diálogo produtivo e alinhado - ainda que não explícito - entre a ideia que a autora tem do que é comunicar e a relação de seu pensamento com o modelo praxiológico (relacional) de comunicação defendido por Quéré em detrimento de um modelo epistemológico (informacional), estanque e onde as mediações inexistem.

O consumo nas três gerações analisadas parece tomar um grau de distanciamento considerável quando a questão da mediação tecnológica e situacional está em jogo. Numa leitura ampla, é possível observar que os modos de escuta são nitidamente diferenciados. Os exemplos da escuta do jovem que ouve o programa de humor na internet para ver o cenário da estação de rádio; da escuta do pai que sempre liga à noite o rádio instalado embaixo da cama e a escuta da avó que diariamente ouve programas espíritas nas emissoras locais, parecem ilustrar bem estas distinções.

E, assim como a pesquisadora afirma, tais diferenciações de modo algum são mais ou menos "corretas" para uma geração ou outra. Na realidade elas sinalizam a predisposição à escuta do rádio em diferentes épocas e circunstâncias. Como García Canclini comenta, ao tratar do consumo de bens simbólicos e culturais de meios tradicionais em outros formatos da internet, este consumo tende a tornar-se cada vez 
mais diversificado, o que possibilita apreciar repertórios culturais e estéticos antes impensados na relação "rádio-ouvinte" (2008, p. 28).

De todas estas inferências e informações levantadas pela pesquisadora, duas delas chamam mais a atenção do leitor: a ideia do rádio como paisagem sonora e a experiência estética radiofônica no ambiente doméstico, o que ocorre quando a escuta do rádio permanece como atividade secundária durante uma tarefa doméstica ou como modo de descanso, "preenchendo" o espaço do lar de uma das famílias da periferia estudada. O rádio é visto como um "personagem" presente nos cômodos da casa que ora resiste, ora adapta-se às inovações. Sempre perpassando, nos distintos modos de escuta, por todas as três gerações.

Ao fim do livro, no quinto e último eixo, Mônica Kaseker contrapõe as três gerações estudadas nas dez famílias e os modos de escuta de seus membros. Depreendese dos resultados mostrados pela pesquisadora, que a primeira geração, por ter vivido de perto o auge das emissoras de rádio no país, ainda possui um forte sentimento de "pertencimento" à escuta radiofônica como meio de informação, entretenimento, religiosidade e, até mesmo, como alternativa ao resgate da memória auditiva de músicas e programas de seu tempo (como o exemplo do programa informativo "Voz do Brasil", no ar e em cadeia nacional desde 1935).

Já a segunda geração, mesmo tendo um acesso mais contínuo às rádios em casa e com a flexibilidade da escuta em carros, ainda assim, permanece mais acostumada à presença da televisão e à sensação de modernidade que o aparelho trouxe aos lares logo no início da implantação das emissoras no Brasil. A terceira geração, por sua vez, é explicitamente multimidiática, ou seja, transita entre a televisão, o rádio, o celular, o computador, os jornais e as revistas, mas vê na internet o espaço ideal onde as possibilidades de convergências de todos os outros meios de comunicação podem ser efetivamente realizadas. $\mathrm{O}$ rádio para esta última geração já não possui a equivalência da carga emocional que possuía para as outras duas gerações anteriores: ele é mais um canal de informação ou conhecimento e, às vezes, não o principal.

É neste ponto que a autora fomenta, ao finalizar sua obra, a imperiosa necessidade dos exercícios de estímulo à escuta (em especial nos mais jovens), numa espécie de "passo-a-passo" das atividades que objetivam a reversão da regressão auditiva. 
É preciso estar em atitude de escuta - e neste sentido, o termo está intimamente ligado à ideia de "(re)descoberta do comum" - para ouvir os sons do ambiente doméstico, da rua e da cidade, do aumento de repertório musical plural e de uma comunicação interpessoal onde "ouvir" corresponda quase que de modo sinonímico a "interagir" com o outro. Aqui, a fala da autora aproxima-se muito daquilo que Gumbrecht (2006, p. 55) acredita quando disserta sobre a experiência estética como uma inesperada interrupção da aparente banalidade cotidiana.

Em suma, uma das grandes contribuições que a obra de Mônica Kaseker traz é que o livro não está destinado apenas aos acadêmicos de Comunicação, Sociologia ou qualquer uma das áreas das Ciências Humanas e das Sociais Aplicadas. Pelo contrário: "Modos de ouvir" apresenta, a quem tiver interesse, quais são os sentidos que a "recepção da escuta radiofônica" vai ganhando no decorrer das relações entre três gerações que, mesmo tendo visões díspares do passado e do futuro, convivem com o rádio num mesmo e compartilhado presente.

\section{REFERENCIAS}

DEL BIANCO, Nera. Rádio e o cenário da convergência tecnológica. In: (org.). O rádio brasileiro na era da convergência midiática. São Paulo: e-livros INTERCOM, 2012.

GARCÍA CANCLINI, Néstor. Leitores, espectadores e internautas. Trad. Ana Goldberger. São Paulo: Iluminuras, 2008.

GUMBRECHT, Hans Ulrich. Pequenas crises: experiências estéticas no mundo cotidiano. Trad. Georg Otte. In: GUIMARÃES, César; LEAL, Bruno S.; MENDONÇA, Carlos C. Comunicação e experiência estética. Belo Horizonte: Editora UFMG, 2006.

MARTÍN-BARBERO, Jesús. Dos meios às mediações: comunicação, cultura e hegemonia. Trad. Ronald Polito; Sérgio Alcides. $6^{\text {a }}$ ed. Rio de Janeiro: Editora UFRJ, 2009.

Oficio de cartógrafo: travesías latinoamericanas de la comunicación en la cultura. Santiago, Chile: Fondo de Cultura Económica, 2002.

MEAD, Margaret. Cultura y compromiso: un estudio sobre la ruptura generacional. Trad. Eduardo Goligorsky. $3^{\mathrm{a}}$ ed. Barcelona, Espanha: Editorial Gredisa, 1997. 
QUÉRÉ, Louis. O caráter impessoal da experiência. Trad. Fernando Scheibe. In: In: LEAL, Bruno S.; MENDONÇA, Carlos C.; GUIMARÃES, César (org.). Entre o sensível e o comunicacional. Belo Horizonte: Autêntica Editora, 2010. 